\title{
Analisis Pertumbuhan Ekonomi Inklusif Kabupaten Timor Tengah Utara
}

\author{
Frederic Wiston Nalle ${ }^{\mathrm{a}}$ \\ ${ }^{a}$ Fakultas Ekonomi dan Bisnis, Universitas Timor, Kefamenanu, TTU - NTT, Indonesia.
}

\section{Article Info}

\section{Article history:}

Received 8 Mei 2017

Received in revised form 3 Juli 2018

Accepted 28 Juli 2018

DOI:

https://doi.org/10.32938/ag.v3i3.452

Keywords:

Pertumbuhan Inklusif

Sektor Unggulan

Kemiskinan disparitas

Faktor Produksi

\section{Abstrak}

Penelitian ini bertujuan untuk mengetahui 1) sektor manakah yang dapat memacu pertumbuhan inklusif; dan 2) bagaimana cara mendorong sektor yang dapat memacu pertumbuhan ekonomi inklusif di Kabupaten TTU. Metode yang dipergunakan dalam rangka menjawab rumusan masalah penelitian ini adalah dengan menggunakan Analisis Deskriptif Kuantitatif dan Kualitatif. Hasil penelitian menunjukkan bahwa berdasarkan kajian Analisis Tipologi Klassen di Kabupaten TTU yang dibedakan menjadi dua bagian, yaitu a) Tipologi Daerah, guna melihat posisi perekonomian Kabupaten TTU di tingkat Provinsi NTT; dan b) tipologi klassen (modification) dengan menggunakan data pertumbuhan dan tenaga kerja per sektor Kabupaten TTU, maka secara spesifik adalah i) berdasarkan analisis tipologi daerah Provinsi NTT dari tahun 2008-2012, dapat disimpulkan bahwa kondisi perekonomian Kabupaten TTU berada dalam kuadran II (daerah berkembang), namun demikian pertumbuhan ekonomi Kab. TTU masih bersifat eksklusif; ii) berdasarkan analisis tipologi klassen pertumbuhan dan tenaga kerja sektoral menunjukkan bahwa yang termasuk dalam kuadran (I) sebagai sektor unggulan dan merupakan sektor yang dapat memacu pertumbuhan ekonomi inklusif di Kabupaten TTU adalah sektor pertanian; iii) menyadari bahwa sektor pertanian merupakan sektor yang dapat mewujudkan pertumbuhan inklusif, maka diperlukan penerapan strategi yang tepat agar sektor pertanian dapat dijadikan sebagai lokomotif pembangunan dan memberikan multipier efect kepada sektor sekunder dan tersier yang secara empiris tergabung dalam sektor terbelakang; dan iv) ada indikasi bahwa pertumbuhan sektor pertanian walaupun meningkatkan penyediaan lapangan pekerjaan yang cukup besar, namun ada kecenderungan makin meningkatkan kemiskinan. Tiga jenis aspek utama yang menyebabkan pertumbuhan sektor pertanian masih belum inklusif antara lain: Tingginya Ketimpangan Struktur Kepemilikan Lahan, Rendahnya Aksebilitas Pasar, dan Rendahnya Aksebilitas Teknologi.

\section{Pendahuluan}

Pembangunan merupakan suatu proses multidimensi yang melibatkan perubahan struktur sosial. Perubahan tersebut didasarkan pada tiga orientasi utama, yaitu i) terjadinya akselerasi ekonomi; ii) pengurangan ketimpangan pendapatan; dan iii) pengurangan kemiskinan absolut (Todaro, 1999). Ketiganya dapat diwujudkan jika terdapat usaha untuk menaikkan produktivitas per kapita, yang dapat dilakukan dengan jalan menambah peralatan modal dan keahlian (SDM). Selain itu, kenaikan ini juga mengharuskan terciptanya nilainilai pembangunan, yang mencakup kebutuhan hidup, harga diri, dan kebebasan yang menggambarkan tujuan-tujuan umum yang diusahakan oleh individu dan masyarakat. Kenaikan pendapatan per kapita dan terjadinya beberapa perubahan sosial mengindikasikan bahwa pembangunan yang optimal mengharuskan terciptanya pertumbuhan ekonomi (economic growth) yang berkualitas, yaitu yang mengedepankan aspek pemerataan pendapatan (Stiglitz \& Uzawa, 1969). Selain itu pertumbuhan ekonomi yang berkualitas disebut sebagai pertumbuhan yang inklusif, yang sangat ditentukan oleh i) pengurangan kemiskinan; ii) menyempitnya ketimpangan struktural; iii) meningkatnya perlindungan sosial; dan iv) pertumbuhan ekonomi secara berkelanjutan (Thomas, 1997).

Beberapa permasalahan perencanaan pembangunan sehingga kontra produktif dengan tujuan esensi otonomi dan kurang optimalnya peran dan fungsi pemerintah daerah merupakan isu utama di Kabupaten Timor Tengah Utara (TTU), yang merupakan salah satu Kabupaten dalam wilayah Provinsi Nusa Tenggara Timur (NTT). Bila dilihat di TTU, desentralisasi fiskal sebenarnya memang menjadi sangat penting karena Kabupaten TTU mempunyai karakteristik wilayah yang beragam, jelas kebutuhan akan pembangunan dalam setiap daerah juga akan berbeda. Keragaman ini dapat dilihat dari jumlah etnis dan karakter wilayah dengan jumlah yang cukup banyak, atau dengan kata lain Kabupaten TTU mempunyai beberapa wilayah yang beragam, di samping perbedaan karakteristik antar wilayah dan permasalahannya. Namun dalam perkembangannya, terdapat indikasi bahwa pelaksanaan desentralisasi fiskal di Kabupaten TTU kurang optimal. Hal ini dapat dilihat dari beberapa indikator pembangunan ekonomi yang kurang memperlihatkan kinerja yang baik, sehingga pembangunan inklusif masih belum dapat dilaksanakan dengan baik.

Isu belum optimalnya perencanaan pembangunan yang berkualitas di Kabupaten TTU diindikasikan oleh beberapa fakta sebagai berikut: Pertama, pembangunan yang dilaksanakan selama ini belum merepresentasikan visi misi daerah. Visi Kabupaten TTU adalah "Terwujudnya masyarakat TTU yang sejahtera, adil, demokratis, dan mandiri melalui pemberdayaan potensi sumber daya insani dan sumber daya alam daerah". Dalam visi tersebut tercermin harapan di masa yang akan datang, bahwa Kabupaten TTU akan menjadi daerah yang mandiri melalui pemberdayaan potensi insani dan sumber daya alam daerah yang dimiliki, mengingat sumberdaya maupun potensi lain Kabupaten TTU ini cukup besar.

Kedua, dilihat dari pertumbuhan menurut lapangan usaha, Kabupaten TTU mempunyai tingkat pertumbuhan secara rata-rata tahun 2007-2012 sebesar 5,05\%. Akan tetapi ada jurang yang cukup besar antara kontribusi sektor pertanian dengan sektor lainnya dalam pembentukan PDRB. Perekonomian Kabupaten TTU masih didominasi oleh kontribusi sektor pertanian tapi tidak didukung oleh sektor penunjang lainnya. Hal itu bahwa dari sembilan (9) sektor yang ada, sektor pertanian memberikan kontribusi $8,76 \%$ dan sektor Industri Pengolahan sebesar 6,45\%. Sedangkan sektor yang mempunyai laju pertumbuhan rata-rata yang paling rendah dan diperlukan perhatian serius dari Pemerintah Kabupaten TTU adalah sektor Pertambangan dan Penggalian yang nilai rata-rata pertumbuhannya tergolong sangat rendah yaitu sebesar 0,64\%, selain itu juga sektor Listrik, Gas dan Air bersih sebesar $3,12 \%$, dan sektor Jasa- Jasa dengan laju pertumbuhan sebesar $1,95 \%$.

Ketiga, pertumbuhan ekonomi Kabupaten TTU yang cenderung fluktuatif turut memberikan gambaran lemahnya kinerja perekonomian daerah. Ini mengindikasikan pula bahwa masih belum optimalnya para perencana daerah memanfaatkan segala potensi yang dimiliki. Hal ini terbukti, dimana pada tahun 2008 berada pada posisi $5,68 \%$, kemudian mengalami penurunan drastis pada tahun 2009 dengan besaran nilai pertumbuhan sebesar 1,20\%, kemudian kembali mengalami kenaikan yang cukup signifikan di tahun 2010 menjadi $10,92 \%$, kembali mengalami penurunan tajam sebesar $2,55 \%$ pada tahun 2011, dan pada tahun 2012 bertumbuh sebesar 4,92\%, dan jika dikalkulasi maka rata-rata pertumbuhan ekonomi selama periode analisis sebesar $5,05 \%$.

Keempat, walaupun pertumbuhan ekonomi Kabupaten TTU memiliki trend positif selama periode analisis, akan tetapi nilai pertumbuhannya sangat fluktuatif dan masih tidak menentu. Hal ini disebabkan juga akibat dari adanya penurunan kontribusi sektor pertanian dan sektor listrik, gas dan air minum. Sektor pertanian yang seharusnya menjadi tulang punggung perekonomian Kabupaten TTU mengalami perlambatan pertumbuhan, salah satu penyebabnya adalah ketika pada tahun 2008 pemerintah daerah membuka kran kebijakan investasi di sektor pertambangan yang ditandai dengan adanya penerbitan surat izin pertambangan bagi enam puluh tiga perusahaan tambang batu mangan untuk menggarap beberapa titik lokasi pertambangan di Kabupaten TTU (Dinas Pertambangan Kab. TTU). Dampak ikutan dari kebijakan jangka pendek ini adalah banyak penduduk yang awalnya bekerja sebagai petani, meninggalkan lahan pertanian mereka dan migrasi ke sektor pertambangan. Akan tetapi, jika dilihat dari data PDRB yang ada, maraknya kehadiran perusahaan tambang justru tidak memberikan dampak yang signifikan bagi peningkatan PDRB di sektor ini. Salah satu syarat dalam mencapai pertumbuhan yang inklusif adalah ketika pertumbuhan ekonomi yang ada mampu menekan angka ketimpangan pendapatan bagi masyarakat yang ada di dalamnya. Ukuran hubungan linear negatif dari dua variabel inilah yang dapat memberikan gambaran apakah telah terjadi distribusi pendapatan yang baik atau belum guna mencapai pertumbuhan yang berkualitas Seharusnya, kondisi ideal yang diharapkan adalah ketika adanya pertumbuhan yang makin tinggi harus dibarengi pula dengan penurunan angka ketimpangan pendapatan. Namun, fakta yang ada bahwa ternyata hal itu belum terlihat dalam kinerja perekonomian Kabupaten TTU.

Kelima, indikator makro ekonomi lainnya yang tidak kalah penting untuk meneropong upaya pencapaian pertumbuhan yang inklusif di daerah adalah dengan mengkaji bagaimana hubungan antara pertumbuhan ekonomi dan Indeks Pembangunan Manusia (IPM) di Kabupaten TTU. Kondisi yang diharapkan adalah ketika adanya pertumbuhan ekonomi yang tinggi maka seharusnya diikuti pula dengan semakin membaiknya angka indeks pembangunan manusia (IPM). Akan tetapi hasil analisis menunjukkan bahwa ternyata masih terdapat hubungan yang tidak berkorelasi kuat, dimana pertumbuhan ekonomi yang tinggi justru tidak mampu ikut memacu kenaikan angka indeks pembangunan manusia.

Keenam, ketimpangan pendapatan di Kabupaten TTU sejalan dengan persentase angka kemiskinan yang cukup tinggi. Berdasarkan data yang dilansir Badan Pusat Statistik Provinsi NTT, persentase angka kemiskinan di Kabupaten TTU rata-rata masih di atas persentase penduduk miskin Provinsi NTT. Jika ditarik hubungan antara pertumbuhan dan tingkat kemiskinan maka dapat diketahui bahwa di Kabupaten TTU belum 
menunjukkan adanya pertumbuhan yang inklusif sebab peningkatan pertumbuhan ekonomi tidak diikuti dengan penurunan angka kemiskinan.

Beberapa permasalahan di atas menggiring pada isu bahwa potensi yang ada dalam Kabupaten TTU belum dioptimalkan secara penuh. Kontradiksi antara pertumbuhan ekonomi dengan beberapa variabel makro untuk melihat kinerja perekonomian seperti masih tingginya tingkat ketimpangan pendapatan, angka pengangguran, tingginya kemiskinan, serta Indeks Pembangun Manusia (IPM) yang cenderung stagnan dan terkategori rendah, maka hal ini mengindikasikan bahwa Kabupaten TTU mengalami kondisi perekonomian yang masih bersifat eksklusif. Sehingga salah satu tantangan utama yang dihadapi pemerintah Kabupaten TTU sebagai lembaga yang bertanggungjawab terhadap perencanaan dan pelaksanaan pembangunan daerah adalah pengetahuan dan pemahaman akan potensi-potensi daerah yang ada di wilayahnya dalam mewujudkan pertumbuhan yang inklusif di Kabupaten TTU. Pengetahuan ini diharapkan sebagai faktor pendorong terwujudnya pertumbuhan ekonomi yang inklusif, yaitu pesatnya laju pertumbuhan ekonomi di Kabupaten TTU yang diiringi dengan penyerapan tenaga kerja, pengurangan angka kemiskinan, ketimpangan pendapatan, peningkatan angka IPM, pemanfaatan faktor endowment, dan terwujudnya pemerataan kesejahteraan.

Menyadari akan pentingnya peran pemerintah daerah dalam mewujudkan pertumbuhan ekonomi inklusif, maka yang menjadi pertanyaan besar dalam penelitian ini adalah bagaimana cara mewujudkan pertumbuhan yang inklusif di Kabupaten Timor Tengah Utara dengan cara penggalian dan pemanfaatan potensi daerah yang dimiliki. Oleh karena itu tujuan yang ingin dicapai dalam penelitian ini adalah untuk mengetahui 1) sektor manakah yang dapat memacu pertumbuhan inklusif; dan 2) bagaimana cara mendorong sektor yang dapat memacu pertumbuhan ekonomi inklusif di Kabupaten TTU.

\section{Metode}

Penelitian dilakukan di Kabupaten TTU. Pemilihan Kabupaten TTU karena permasalahan perencanaan pembangunan masih belum berjalan optimal. Penelitian ini menggunakan pendekatan deskriptif kuantitatif. Selain itu juga dilakukan secara eksploratif yang dimaksudkan agar bisa menggali lebih dalam dari objek yang diteliti sesuai petunjuk Sugiyono, (2006).

Berdasarkan metode analisis, kebutuhan data penelitian ini terbagi menjadi dua macam. Pertama adalah data sekunder, yang dalam penelitian ini diperoleh melalui dinas/instansi terkait. Kedua, data primer, yang dalam penelitian ini diperoleh melalui observasi dan wawancara.

Dalam penelitian ini, ada beberapa teknik yang digunakan untuk mengumpulkan data, yaitu dokumentasi, observasi, dan wawancara. Ketiga teknik tersebut dilakukan dengan menggunakan teknik pendalaman tidak terstruktur (tanpa kuesioner). Selanjutnya metode analisis dalam penelitian ini dimulai dengan melakukan proses identifikasi dan pemetaan sektor unggulan Kabupaten TTU. Ada dua faktor yang dipertimbangkan dalam mengidentifikasi sektor unggulan Kabupaten TTU, yaitu i) sektor ekonomi unggul atau mempunyai daya saing; dan ii) sektor ekonomi potensial dimasa yang akan datang, walaupun saat ini belum memiliki daya saing yang baik. Untuk dapat memetakan potensi daerah secara sektoral yang didasarkan pada data PDRB, akan digunakan Analisis Tipologi Klassen (Mahmudi, 2010).

Penentuan suatu sektor apakah masuk dalam kategori prima, potensial, berkembang, dan terkebelakang didasarkan pada perhitungan laju pertumbuhan kontribusi sektoral dan rerata besar kontribusi sektoralnya terhadap PDRB, seperti yang ditujukan dalam Tabel 1.

Tabel 1. Kategori Daerah Berdasarkan Tipologi Klassen

\begin{tabular}{ccc}
\hline Rata-rata laju & \multicolumn{2}{c}{ Rata-rata Kontribusi Sektoral terhadap PDRB } \\
\cline { 2 - 3 } Pertumbuhan Sektoral & yi SEKTOR $\geq \tilde{Y}$ PDRB & yi SEKTOR $\leq \tilde{Y}$ k PDRB \\
\hline ri SEKTOR $\geq$ RPDRB & Daerah Maju & Daerah Berkembang \\
ri SEKTOR $\leq$ RPDRB & Daerah Potensial & Daerah Terbelakang \\
\hline
\end{tabular}

Selanjutnya untuk melihat kontribusi sektoral dan penyerapan tenaga kerja sektoral digunakan tipologi klassen modifikasi. Alat analisis ini digunakan untuk mencari tahu sektor mana yang dapat diandalkan untuk mewujudkan pertumbuhan inklusif di Kabupaten TTU. Data yang digunakan dalam metode pendekatan ini adalah dengan memodifikasi model pendekatan tipologi klassen yang umumnya digunakan, yaitu data pertumbuhan dan tenaga kerja per sektor ekonomi/industri pembentuk PDRB di Kabupaten TTU.

Kemudian untuk menjawab bagaimana strategi yang harus dilakukan oleh Pemerintah Daerah Kabupaten TTU untuk dapat mewujudkan pertumbuhan inklusif digunakan analisis deskriptif. Analisis deskriptif dalam penelitian ini, adalah mencoba menggali lebih jauh dan mengulas secara mendalam berdasarkan hasil olahan data dengan metode pendekatan tipologi klassen, pengumpulan data primer, observasi dan publikasi jurnal ilmiah agar dapat mengulas bagaimana strategi seharusnya diambil oleh pemerintahan daerah untuk mendorong sektor yang dapat memacu pertumbuhan inklusif di Kabupaten TTU.

\section{Hasil dan Pembahasan}

3.1 Tipologi Klassen Kabupaten TTU di Tingkat Provinsi NTT

Dengan menggunakan data PDRB Kabupaten TTU periode tahun 20072012, dilakukan analisis kinerja sektoral ekonomi pembentuk PDRB. Namun, langkah awal analisis yang dilakukan adalah melihat hasil analisis tipologi daerah Kabupaten TTU di tingkat Provinsi NTT. Hal ini dimaksudkan agar penelitian ini dapat melihat dimana posisi keberadaan Kabupaten TTU untuk tingkat Provinsi.

Berkaitan dengan tipologi klassen di atas, jumlah kota/kabupaten yang diamati pada penelitian ini adalah sebanyak 21 kota/kabupaten yang diamati pada tahun 2007 sampai dengan tahun 2012. Hasil pengujian didapatkan sebaran kuadran seperti pada Tabel 2.

Tabel 2. Klasifikasi Kabupaten/Kota di Provinsi NTT Berdasarkan Analisis Tipologi Klassen Tahun 2008

\begin{tabular}{lll}
\hline \multirow{2}{*}{$\begin{array}{c}\text { Laju } \\
\text { Pertumbuhan }\end{array}$} & \multicolumn{2}{c}{ PDRB Per kapita } \\
\cline { 2 - 3 } & yi $>$ Y PDRB (Kuadran I) & \multicolumn{1}{c}{ yi < Y PDRB (Kuadran II) } \\
\hline \multirow{4}{*}{ ri $>$ R PDRB } & Daerah cepat maju dan cepat & Daerah berkembang Cepat \\
& 1. Sumba Timur & 1. Timor Tengah Utara \\
& 2. Belu & 2. Manggarai Barat \\
& 3. Sika & \\
& 4. Rote Ndao & \\
5. Kota Kupang & \\
\hline & Daerah maju tapi tertekan & Daerah relatif Tertinggal \\
& (Kuadran III) & (Kuadran IV) \\
& 1. Sumba Barat & 1. Timor Tengah Selatan \\
& 2. Kupang & 2. Alor \\
3. Flores Timur & 3. Lembata \\
ri $<$ R PDRB & 4. Ende & 4. Manggarai \\
& 5. Ngada & 5. Sumba Barat Daya \\
& & 6. Sumba Tengah \\
& & 7. Nagekeo \\
& & 8. Manggarai Timur \\
& & 9. Sabu Raijua \\
\hline
\end{tabular}

Sumber : Badan Pusat Statistik NTT 2007-2012, (Data Diolah)

Selanjutnya untuk analisis tahun 2012 didapatkan daerah yang termasuk dalam kuadran tertentu yaitu:

a. Kuadran I (Daerah Cepat Maju dan Cepat Tumbuh) yaitu Sumba Barat, Sumba Timur, Belu, Ende, Ngada Rote Ndao, dan Kota Kupang.

b. Kuadran II (Daerah Berkembang Cepat) yaitu Timor Tengah Utara, Manggarai, dan Sabu Raijua.

c. Kuadran III (Daerah Maju tapi Tertekan) yaitu Kupang, Flores Timur, dan Sikka.

d. Kuadran IV (Daerah Relatif Tertinggal) yaitu Timor Tengah Selatan, Alor, Lembata, Manggarai Barat, Sumba Barat Daya, Sumba Tengah, Nagekeo, dan Manggarai Timur.

Tabel 3. Klasifikasi Kabupaten/Kota di Provinsi NTT Berdasarkan Analisis Tipologi Klassen Tahun 2012

\begin{tabular}{|c|c|c|}
\hline \multirow{2}{*}{$\begin{array}{l}\text { Laju } \\
\text { Pertumbuhan }\end{array}$} & \multicolumn{2}{|c|}{ PDRB Per kapita } \\
\hline & yi > Y PDRB (Kuadran I) & $\begin{array}{c}\text { yi < Y PDRB } \\
\text { (Kuadran II) }\end{array}$ \\
\hline ri $>\mathrm{R}$ & $\begin{array}{l}\text { Daerah cepat maju dan cepat } \\
\text { tumbuh } \\
\text { 1. Sumba Barat } \\
\text { 2. Sumba Timur } \\
\text { 3. Belu } \\
\text { 4. Ende } \\
\text { 5. Ngada } \\
\text { 6. Rote Ndao } \\
\text { 7. Kota Kupang }\end{array}$ & $\begin{array}{l}\text { Daerah berkembang } \\
\text { Cepat } \\
\text { 1. Timor Tengah } \\
\text { Utara } \\
\text { 2. Manggarai } \\
\text { 3. Sabu Raijua }\end{array}$ \\
\hline $\mathrm{ri}<\mathrm{R}$ & $\begin{array}{l}\text { Daerah maju tapi tertekan } \\
\text { (Kuadran III) } \\
\text { 1. Kupang } \\
\text { 2. Flores Timur } \\
\text { 3. Sikka }\end{array}$ & $\begin{array}{l}\text { Daerah relatif } \\
\text { Tertinggal (Kuadran } \\
\text { IV) } \\
\text { 1. Timor Tengah } \\
\text { Selatan } \\
\text { 2. Alor } \\
\text { 3. Lembata } \\
\text { 4. Manggarai Barat } \\
\text { 5. Sumba Barat Daya } \\
\text { 6. Sumba Tengah } \\
\text { 7. Nagekeo } \\
\text { 8. Manggarai Timur }\end{array}$ \\
\hline
\end{tabular}

Sumber : Badan Pusat Statistik NTT 2007-2012, (Data Diolah)

Berdasarkan analisis tipologi daerah Provinsi NTT dari tahun 2008-2012 di atas, dapat disimpulkan bahwa kondisi perekonomian Kabupaten TTU masih relatif stabil dan stagnan terkategori dalam kuadran II (daerah berkembang cepat). Hal ini tentu menjadi informasi yang menarik bagi pemerintah daerah, 
namun belum bisa menggambarkan secara komprehensif pertumbuhan ekonomi inklusif yang menyeluruh yang pada akhirnya mampu membawa dampak bagi kesejahteraan masyarakat secara utuh. Oleh karena itu, dengan menggunakan metode pendekatan yang sama, perlu dikaji lebih jauh kontribusi ekonomi sektoral dan penyerapan tenaga kerja di Kabupaten TTU.

\subsection{Tipologi Klassen Pertumbuhan Sektoral dan Tenaga Kerja}

Analisis ini dilakukan untuk dapat melihat sektor manakah yang dapat memacu pertumbuhan inklusif di Kabupaten Timor Tengah Utara. Model pengukuran dalam analisis tipologi klassen di sini adalah dengan sedikit memodifikasi data, agar pengukuran yang dilakukan benar-benar valid dalam menjawab persoalan pembangunan ekonomi di Kabupaten TTU. Data yang dipergunakan adalah data tenaga kerja per sektor dan juga data pertumbuhan per sektor ekonomi/industri selama periode analisis tahun 20082012. Hasil analisisnya dapat dilihat dalam tabel di bawah ini.

\section{Tabel 4. Hasil Rata-Rata PDRB Per Sektor}

\begin{tabular}{lcc}
\hline \multicolumn{1}{c}{ Sektor } & $\begin{array}{c}\text { Pertumbuhan } \\
\text { PDRB per Sektor }\end{array}$ & $\begin{array}{c}\text { Rata-rata Tenaga } \\
\text { Kerja per Sektor }\end{array}$ \\
\hline Pertanian & 8,58 & 80.457 \\
Pertambangan \& Penggalian & $-1,08$ & 332 \\
Industri Pengolahan & 4,46 & 6.155 \\
Listrik, Gas \& Air Minum & 6,58 & 264 \\
Bangunan / Konstruksi & 5,73 & 2.766 \\
Perdagangan, Restoran, Hotel & 1,97 & 2.446 \\
Pengangkutan dan Komunikasi & 0,77 & 3.287 \\
Keuangan, Persewaan \& Jasa & $-3,33$ & 99 \\
Perusahaan & $-0,21$ & 8.030 \\
Jasa - jasa & & \multirow{2}{*}{3,92} \\
Rata-rata PDRB dibagi 6 tahun periode & & 25.959 \\
analisis & & \\
\hline
\end{tabular}

Sumber: Badan Pusat Statistik Kabupaten TTU Tahun 2007-2012 (Data Diolah)

Dari hasil olahan data Tabel 4. maka dapat dilakukan pemetaan sektoral untuk menentukan keberadaan tiap sektor dalam analisis Tipologi Klassen dengan pendekatan pertumbuhan sektoral dan tenaga kerja.

Tabel 5. Tabel Matriks Tipologi Klassen (Modifikasi)

\begin{tabular}{|c|c|c|}
\hline \multirow{2}{*}{$\begin{array}{c}\text { Rata-rata laju } \\
\text { Pertumbuhan } \\
\text { Sektoral } \\
\end{array}$} & \multicolumn{2}{|c|}{ Rata-rata Kontribusi Sektoral Terhadap PDRB } \\
\hline & $\begin{array}{c}\tilde{Y} \text { i SEKTOR } \geq \tilde{Y} \text { Tenaga } \\
\text { Kerja }\end{array}$ & Yi SEKTOR $\leq \tilde{Y}$ Tenaga Kerja \\
\hline \multirow{5}{*}{ rSEKTOR $\geq$ RPDRB } & $\begin{array}{l}\text { Sektor Unggulan } \\
\text { Pertanian }\end{array}$ & $\begin{array}{l}\text { Sektor Berkembang Industri } \\
\text { Pengolahan }\end{array}$ \\
\hline & & $\circ \quad$ Industri Pengolahan \\
\hline & & Bangunan / Konstruksi \\
\hline & & Sektor Listrik Gas dan \\
\hline & & $\circ \quad$ Air Minum \\
\hline \multirow{9}{*}{ rSEKTOR $\leq$ RPDRB } & Sektor Potensial & Sektor Terbelakang \\
\hline & & - Pertambangan dan \\
\hline & & Penggalian \\
\hline & & $\begin{array}{l}\text { - Perdagangan, Restoran } \\
\text { Hotel }\end{array}$ \\
\hline & & Pengangkutan dan \\
\hline & & Komunikasi \\
\hline & & Keuangan Persewaan dan \\
\hline & & Jasa Perusahaan \\
\hline & & Sektor jasa \\
\hline
\end{tabular}

Sumber: Badan Pusat Statistik NTT Tahun 2007-2012 (Data Diolah)

Berdasarkan matriks tipologi klassen (modifikasi) dapat ditarik kesimpulan bahwa secara keseluruhan dari sembilan sektor ekonomi, yang berada dalam kuadran (I) sektor unggulan dan merupakan sektor yang dapat mendorong terwujudnya pembangunan inklusif di Kabupaten TTU adalah sektor pertanian Adapun sektor-sektor yang tergabung dalam kuadran sektor berkembang antara lain i) sektor industri pengolahan; dan ii) sektor bangunan atau konstruksi dan sektor listrik gas dan air minum. Sementara sektor-sektor yang tergabung dalam kuadran sektor terbelakang antara lain i) sektor pertambangan dan penggalian; ii) sektor perdagangan, restoran dan hotel; iii) sektor pengangkutan dan komunikasi; iv) sektor keuangan persewaan dan jasa perusahaan serta; dan v) sektor jasa.

\subsection{Persoalan Pembangunan Sektor Pertanian}

Meskipun sektor pertanian cukup penting di Kabupaten TTU, namun kemiskinan masih menjadi masalah yang krusial dengan jumlah penduduk miskin mencapai 26.465 jiwa atau sebesar $22,73 \%$ dari total jumlah penduduk (BPS Kab. TTU, 2015). Kemiskinan yang terjadi ini lebih dipicu oleh rendahnya kualitas Sumber Daya Manusia atau sebagian besar masyarakat yang bekerja sebagai petani, masih menggunakan pola tradisional bertani dalam kelangsungan hidup mereka (pertanian sub sistem). Kondisi di atas menandakan bahwa tingginya pertumbuhan sektor pertanian tidak berpengaruh signifikan terhadap pemerataan kesejahteraan di Kabupaten TTU. Fakta ini dapat dilihat dari hubungan antara pertumbuhan sektor pertanian dan tingkat kemiskinan di Kabupaten TTU. Untuk lebih jelasnya maka dapat dilihat dalam Gambar 2.

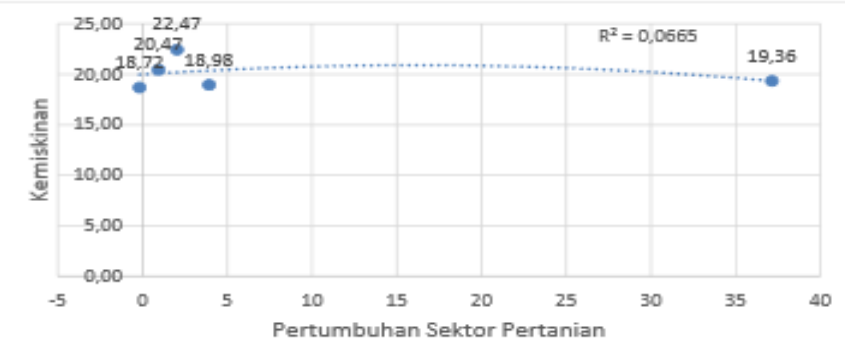

Sumber: Badan Pusat Statistik Kabupaten TTU Tahun 2008-2012 (Data Diolah)

Gambar 1. Hubungan Pertumbuhan Sektor Pertanian dan Tingkat Kemiskinan di Kabupaten TTU

Berdasarkan Gambar 2. dapat ditarik kesimpulan bahwa berapapun besarnya persentase pertumbuhan di sektor pertanian akan tetapi tetap tidak memberikan dampak yang signifikan terhadap penurunan angka kemiskinan. Mempertegas bahwa masih adanya gejala eksklusitifitas pertumbuhan di sektor pertanian. Makna dari adanya indikasi kontradiksi pertumbuhan sektor pertanian dan kemiskinan di sini menjelaskan bahwa peningkatan value added di sektor pertanian yang cepat belum bisa dinikmati oleh seluruh pelaku usaha tani dan ada kemungkinan hanya dinikmati oleh petani yang memiliki lahan luas dan pihak perantara lainnya sebagai akibat masih terdapat adanya gejala disparitas kepemilikan faktor produksi yang timpang di kalangan petani.

Berdasarkan pengamatan, hasil wawancara dari beberapa informan dan juga diskusi dengan pihak akademisi yang berkompeten dibidang pertanian, maka diperoleh informasi bahwa, rata-rata yang menjadi indikasi bahwa semakin baiknya pertumbuhan di sektor pertanian justru berbanding terbalik dengan tingkat kemiskinan lebih disebabkan oleh beberapa identifikasi temuan antara lain adalah sebagai berikut:

a. Sektor pertanian di Kabupaten TTU ternyata banyak menampung pengangguran terselubung dan angkatan kerja yang kurang berpendidikan dan terampil.

b. Sektor pertanian merupakan sektor yang menampung tenaga kerja dengan tingkat pendidikan yang rendah karena tenaga kerja terdidik tidak ingin menjadi petani.

c. Rendahnya adopsi inovasi paket teknologi pertanian sehingga mengakibatkan produksi dan produktivitas semakin menurun dan berdampak pada tingginya angka kemiskinan di kalangan petani.

d. Terjadi migrasi tenaga kerja antar sektor, dimana masyarakat TTU yang umumnya adalah petani memilih untuk menjadi penambang, ataupun bila tetap melakukan usaha tani sekalipun, waktu dan perhatian yang dicurahkan untuk usaha tani semakin kecil sehingga kemungkinan risiko kegagalan panen semakin tinggi.

e. Intensifikasi pertanian gagal dilakukan, sehingga dalam jangka panjang kemungkinan akan terjadi kelangkaan pangan di Kabupaten TTU.

f. Adanya ketidakseimbangan antara rendahnya harga komoditi pertanian dan mahalnya ketersediaan input produksi pertanian seperti pupuk, obatobatan/pestisida, bibit, dan faktor pendukung lainnya menyebabkan daya beli petani rendah.

g. Harga jual output pertanian tergolong rendah sehingga nilai tambah hasil pertanian untuk turut mendongkrak pendapatan dan kesejahteraan masyarakat petani sulit tercapai.

h. Lemahnya kontrol harga dari pemerintah yang faktanya harga terbentuk karena lebih didominasi oleh para tengkulak dari Kabupaten tetangga seperti Kabupaten Timor Tengah Selatan (TTS) dan Kabupaten Belu.

i. Kesulitan akses pasar yang memadai dalam perdagangan hasil pertanian mengakibatkan rata-rata petani bekerja hanya untuk dapat memenuhi kebutuhan pokok keluarga dan sekedar untuk bisa bertahan hidup.

j. Berdasarkan observasi di Kecamatan Miomaffo Barat, kelimpahan sektor pertanian tidak menjamin tingkat kesejahteraan masyarakatnya. Hal ini akibat tidak adanya industri penyokong sektor pertanian.

k. Masih terdapat luasnya lahan tidur yang tidak dikelola secara baik. Luas lahan tidur di Kabupaten TTU masih sangat luas.

Minimnya peran Perusahaan Daerah (PD) dalam mengatasi persoalan harga komoditi pertanian yang begitu rendah dan dikuasai oleh para tengkulak, sebagai akibat terbatasnya pola kemitraan perdagangan inter regional. Ke-dua belas fenomena di atas, mengindikasikan bahwa pertumbuhan sektor pertanian yang tinggi belum bisa menyejahterakan pelakunya (petani). Padahal mayoritas pekerjaan masyarakat di Kabupaten TTU adalah petani. Dapat dipastikan, ratarata masyarakat di Kabupaten TTU adalah tergolong miskin. Hal in menegaskan bahwa pembangunan sektor pertanian yang terjadi di Kabupaten TTU belum dapat dikatakan inklusif. Data empiris menunjukkan bahwa 
meskipun sektor pertanian menciptakan sumbangan yang besar dalam penciptaan lapangan kerja dan jaminan pendapatan kepada masyarakat, namun ketidakseimbangan sestimik masih sering terjadi pada kelompok masyarakat tani yang sebagian besar ada di perdesaan.

Isma'il $d k k$., (2015), mengatakan bahwa berkaitan dengan pembangunan pengembangan sektor pertanian, terdapat banyak indikasi persoalan yang begitu kompleks dan perlu mendapatkan penanganan serius. Akan tetapi, dari sekian banyak masalah tersebut setidaknya terdapat tiga (3) jenis aspek mendasar yang patut memperoleh prioritas perhatian pemerintah, antara lain:

a. Tingginya Ketimpangan Kepemilikan Lahan;

Persoalan ini lebih dikarenakan oleh adanya distribusi kepemilikan lahan yang timpang. Indikasi dari adanya ketimpangan kepemilikan lahan yang ada di Kabupaten TTU adalah dengan melihat struktur kepemilikan lahan pertanian. Dengan struktur kepemilikan lahan yang seperti ini menandakan bahwa harapan untuk mencapai efisiensi dan produktivitas akan jauh dari harapan. Fakta yang tidak bisa dipungkiri, sebagian besar masyarakat petani memiliki lahan pertanian yang sempit sedangkan yang lain memiliki kepemilikan lahan yang luas dan tergolong sebagai petani kaya

b. Rendahnya Aksebilitas Pasar;

Berhubungan dengan distribusi tata niaga pertanian baik di pasar input maupun pasar output. Hal ini bisa dilihat dari indikasi kemampuan akses pasar antara petani kecil dan petani yang memiliki lahan lebih luas tidak sama. Dimana sebagian besar petani yang memiliki lahan sempit mengatakan bahwa harga input produksi seperti bibit, pupuk, ataupun pestisida relatif mahal. Mengindikasikan bahwa di Kabupaten TTU masih adanya ketidaksempurnaan dalam aksebilitas pasar antara petani miskin (yang memiliki lahan sempit) dan petani kaya (yang memiliki lahan lebih luas). Persoalan lain berkaitan dengan aspek ini yang tidak kalah pentingnya adalah infrastruktur pendukung yang menghubungkan daerah penghasil dan pemasar.

c. Rendahnya Aksebilitas Teknologi;

Berkaitan dengan penggunaan alat-alat produksi yang berhubungan dengan penggunaan teknologi tepat guna bagi petani, dimana alat-alat produksi dalam menggarap lahan pertanian dengan metode yang lebih modern cuma bisa dinikmati oleh petani kaya. Rendahnya adopsi inovasi teknologi pertanian bagi petani kecil ini mengakibatkan produksi dan produktivitas semakin menurun dan berdampak pada tingginya angka kemiskinan di kalangan petani.

Dari ketiga komponen aspek permasalahan ini jika mampu diatasi maka besar kemungkinan kemiskinan di sektor pertanian dapat diatasi dan tujuan tercipta pembangunan inklusif bisa diwujudkan di Kabupaten TTU. Oleh karena itu, upaya pencapaian hal dimaksud sangat tergantung dari strategi atau instrumen kebijakan yang diambil oleh Pemerintah Daerah.

\subsection{Strategi Pembangunan Sektor Pertanian}

Upaya pengentasan kemiskinan secara sistemik dan kelembagaan seharusnya disasar pada simpul-simpul kemiskinan. Dengan berbagai strategi pembangunan dengan ragam program untuk mengatasi persoalan kemiskinan di desa selalu diluncurkan. Beraneka program pembangunan tersebut antara lain melalui pemberdayaan masyarakat, bantuan-bantuan sosial, dana insentif, hibah, penguatan modal maupun pinjaman telah digulirkan kepada masyarakat, baik itu datangnya dari pemerintah ataupun lembaga non pemerintah seperti LSM, Gereja dan lainnya. Akan tetapi faktanya segala jenis bantuan itu tidak memiliki dampak signifikan terhadap upaya pengentasan kemiskinan di Kabupaten TTU.

Isma'il $d k k .$, (2015), jika terjadi fenomena seperti beragam permasalahan pembangunan pengembangan sektor pertanian sebagai potensi daerah yang telah diuraikan di atas, maka secara spesifik strategi utama yang perlu diambil oleh Pemerintah setempat untuk menjawab tiga aspek utama yang menyebabkan belum inklusifnya pertumbuhan sektor pertanian antara lain adalah sebagai berikut:

a. Diversifikasi di sektor pertanian

Jika terjadi ketimpangan kepemilikan lahan maka cara yang paling ideal yang seharusnya dilakukan oleh pemerintah adalah land reform. Yang dimaksud dengan land reform di sini adalah masalah reformasi kepemilikan lahan pertanian sebagaimana yang pernah diperjuangkan Sang Founding Father Soekarno dengan payung hukum Undang-Undang Pokok Agraria (UUPA) tahun 1960. Dasar pertimbangannya sangat jelas bahwa tanah adalah identitas bagi petani. Sebab tanpa tanah, maka petani akan tetap menjadi mangsa eksploitasi pelaku ekonomi lainnya, sehingga kepemilikan tanah merupakan hal yang mutlak dibutuhkan.

Point penting dalam land reform ini adalah bagi mereka yang memiliki lahan yang sangat luas di luar batas ketentuan negara, dibagikan kepada petani yang memiliki lahan sempit atau bahkan tidak memiliki sepetak pun. Banyak negara komunis dan juga Jepang yang berhasil menerapkan strategi ini, dalam upaya mengatasi ketimpangan distribusi lahan dan menekan jumlah penduduk miskin di sektor pertanian. Akan tetapi kebijakan land reform ini tidak mungkin dapat dilakukan oleh pemerintah kita, walaupun sistem undangundang kita mengizinkan hal itu bisa diwujudkan. Sebagaimana yang telah tertuang dalam Pasal 33 ayat 3 UUD 1945 yang menyatakan bahwa; "Bumi dan air dan kekayaan alam yang terkandung di dalamnya dikuasai oleh negara dan dipergunakan sebesar-besarnya demi kemakmuran rakyat”. Alasan mendasar dari tidak mungkin diterapkannya sistem land reform, disebabkan oleh karena dinilai akan terjadi benturan psikologis dan politik yang tidak menguntungkan bagi masyarakat dan juga negara. Akan menjadi sangat sulit bagi mereka yang memiliki lahan luas untuk mau dengan sukarela membagikan lahannya secara cuma-cuma kepada masyarakat miskin lainya.

Oleh karena itu, yang paling mungkin dilakukan pemerintah dengan instrumen kebijakannya adalah diversifikasi usaha tani. Ini dilakukan kepada petani-petani yang memiliki lahan sempit sebab mereka tidak mungkin akan melakukan usaha taninya di lahan yang sempit karena keterbatasan kemampuan dalam akses pasar untuk mencapai harga input produksi yang relatif mahal, seperti yang sudah dijelaskan sebelumnya.

b. Aksebilitas Input maupun Output

Karena hal ini berhubungan dengan tata niaga komoditi pertanian yang tidak bertahan lama atau mudah rusak, maka baik pemerintah Pusat, Provinsi maupun Kabupaten perlu ada sinergi yang kuat dalam mengeluarkan regulasi guna mengatur tata niaga di sektor pertanian baik hasil maupun bahan baku. Regulasi yang diatur dalam tata niaga pertanian ini adalah di dalamnya termasuk mengenai harga dasar/pokok, pajak, hingga pada distribusi pemasaran produk pertanian yang lebih berpihak pada petani kecil.

Selama ini regulasi yang dikeluarkan melalui Perda, dan tertuang dalam Renstrada, RPJMD terkesan sudah sangat baik, akan tetapi masih lemah dalam penerapannya di tingkat teknis sehingga terkesan petani bukan sebagai fokus pembangunan sektor pertanian itu sendiri. Selain itu Infrastruktur transportasi harus berperan sebagai tulang punggung dalam proses produksi maupun dalam menunjang mobilisasi manusia dan distribusi komoditi hasil pertanian.

Selain infrastruktur transportasi yang perlu ditingkatkan, faktor kelembagaan yang berbasis masyarakat guna turut mendukung seluruh rangkaian proses kegiatan industrialisasi berbasis pertanian (agroindustri/agrobisnis) juga sangat dibutuhkan. Oleh karena itu faktor kelembagaan yang perlu ditekankan di sini adalah kelembagaan desa dan kelembagaan desa industri guna turut mendukung pertanian sektor hulu yang pada akhirnya mampu mengangkat kesejahteraan petani.

Eksistensi kelembagaan desa industri ini, diyakini mampu membangkitkan lembaga-lembaga perdesaan yang sudah ada seperti koperasi, maupun lembaga keuangan mikro lainnya. Khusus tentang Badan Usaha Milik Desa (BUMDes) yang keberadaannya menjadi program unggulan pemerintah pusat, seiring dengan UU tentang desa No 6 tahun 2014 tentang Desa Mandiri, kelembagaan industri pedesaan ini dapat menjadi bagian penting dari Bumdes tersebut.

c. Perlu adanya pengembangan teknologi sektor pertanian.

Pembangunan pertanian tidak hanya diarahkan untuk peningkatan produksi, tetapi juga untuk menghasilkan produk berkualitas yang berdaya saing dengan sistem produksi yang modern. Oleh karena itu kerangka kebijakan pengembangan ilmu pengetahuan dan teknologi guna memperkuat pembangunan pertanian harus ditekankan bukan saja pada teknologi pengolahan lahan pertanian akan tetapi juga pada teknologi pangan berbasis pertanian. Untuk meningkatkan daya dukung teknologi maka yang perlu dipikirkan adalah bagaimana upaya memperkuat kelembagaan, menciptakan iklim inovasi, dan membentuk sumber daya manusia yang handal dalam pengelolaan sumber daya. Teknologi merupakan komponen penting dalam menggerakkan industrialisasi desa terutama dalam pembangunan agroindustri.

Penguatan industri perdesaan perlu dilakukan baik untuk industri hulu untuk memasok sarana produksi, alat dan mesin produksi industri perdesaan dalam rangka peningkatan produktivitas; maupun industri hilir untuk penanganan dan pengolahan hasil dalam rangka untuk kehilangan hasil, pengemasan, pengawetan, dan diservikasi hasil produk olahan. Pembangunan industri desa perlu diawali dengan penyiapan sumberdaya manusia (human capital) yang kompeten sesuai dengan posisi dan fungsinya masing-masing, termasuk unsur masyarakat pertanian pada strata yang paling dasar; yakni petani yang memasok bahan bakunya. Tahap selanjutnya adalah meningkatkan kapasitas adopsi teknologi untuk proses produksi dan aktivitas agroindustri lainnya. Human capital yang telah disiapkan pada tahap sebelumnya akan menjadi modal penting untuk keberhasilan adopsi teknologi ini. Adopsi teknologi yang meningkat diharapkan akan meningkatkan produktivitas dan kesejahteraan masyarakat petani di desa.

\section{Simpulan}

Berdasarkan kajian Analisis Tipologi Klassen di Kabupaten TTU yang dibedakan menjadi dua bagian, yaitu a) Tipologi Daerah, guna melihat posis perekonomian Kabupaten TTU di tingkat Provinsi NTT; dan b) tipologi klassen (modification) dengan menggunakan data pertumbuhan dan tenaga kerja per sektor Kabupaten TTU, maka secara spesifik adalah i) berdasarkan analisis tipologi daerah Provinsi NTT dari tahun 2008-2012, dapat disimpulkan bahwa kondisi perekonomian Kabupaten TTU berada dalam kuadran II (daerah berkembang), namun demikian pertumbuhan ekonomi Kab. TTU masih bersifat eksklusif; ii) berdasarkan analisis tipologi klassen pertumbuhan dan tenaga kerja sektoral menunjukkan bahwa yang termasuk dalam kuadran (I) sebagai sektor unggulan dan merupakan sektor yang dapat memacu pertumbuhan ekonomi inklusif di Kabupaten TTU adalah sektor pertanian; iii) menyadari bahwa sektor pertanian merupakan sektor yang dapat mewujudkan pertumbuhan inklusif, maka diperlukan penerapan strategi yang tepat agar sektor pertanian dapat dijadikan sebagai lokomotif pembangunan dan memberikan multipier efect kepada sektor sekunder dan tersier yang secara empiris tergabung dalam sektor terbelakang; dan iv) ada indikasi bahwa pertumbuhan sektor pertanian walaupun meningkatkan penyediaan lapangan pekerjaan yang cukup besar, namun ada kecenderungan makin 
meningkatkan kemiskinan. Hal ini mengindikasikan bahwa pembangunan pengembangan sektor pertanian memiliki tantangan yang cukup berat untuk membuat sektor ini benar-benar inklusif. Tiga jenis aspek utama yang menyebabkan pertumbuhan sektor pertanian masih belum inklusif antara lain: Tingginya Ketimpangan Struktur Kepemilikan Lahan, Rendahnya Aksebilitas Pasar, dan Rendahnya Aksebilitas Teknologi.

\section{Pustaka}

BPS Kab. TTU 2015. Timor Tengah Utara dalam Angka 2015. Kefamenanu: Badan Pusat Statistik Kabupaten TTU.

Isma'il, M., Santosa, D.B. \& Yustika, A.E. 2015. Sistem ekonomi Indonesia: tafsiran Pancasila \& UUD 1945. Jakarta: Penerbit Erlangga.

Mahmudi 2010. Manajemen Keuangan Daerah. Jakarta: Erlangga.

Stiglitz, J.E. \& Uzawa, H. 1969. Readings in the modern theory of economic growth. M.I.T. Press.

Sugiyono, 2006. Metode Penelitian Kuantitatif, Kualitatif dan $R \& D$. Bandung: Alfabeta.

Thomas, R.L. 1997. Modern Econometrics: An Introduction. Boston: AddisonWesley.

Todaro, M.P. 1999. Economics Development in the Third World. New York: The Longman Inc. 